\title{
Rafał CHWEDORUK
}

Uniwersytet Warszawski

\section{O anachroniczności polskiego kapitalizmu - niekonserwatywne krytyki liberalizmu we współczesnej Polsce}

\section{Wstęp}

Wielkie przemiany ustrojowe w Polsce po 1989 roku zaowocowały umieszczeniem szeroko pojętego liberalizmu w centrum dyskursu politycznego. Częste stały się tezy o znaczącej, jeśli wręcz nie determinującej, roli tej tradycji ideowej w określaniu modelu reform społeczno-gospodarczych i ustrojowych. Jednocześnie narastała fala jej dyskredytacji o zróżnicowanej ideowej prowieniencji. Celem niniejszego tekstu jest zaprezentowanie kluczowych wątków krytyki liberalizmu, prowadzonej z pozycji promodernizacyjnych, tj. akceptujących szeroko pojęty paradygmat oświeceniowy, aprobujących imperatyw cywilizacyjnej modernizacji Polski poprzez jej okcydentalizację. Dyskurs liberalnych reformatorów $\mathrm{z}$ ich oponentami w pewnej mierze zdaje się wpisywać w zmitologizowaną diadę lewica-prawica, choć niekoniecznie wielu uczestników sporu musiało dokonywać takiej autoidentyfikacji. Czynnikiem silnie różnicującym wewnętrznie antagonistów rodzimego modelu liberalizmu był stosunek do transformacji ustrojowej - zajmowali oni przestrzeń od jednoznacznej i całkowitej opozycji wobec realizowanych przemian do krytycznej aprobaty jej fundamentów. Generalnie można podzielić środowiska dezawuujące tytułową ideologię (jeśli to zasadne słowo) na trzy grupy. Pierwszą, najdalej idącą w polemikach stanowiły środowiska wyrastające z ruchu solidarnościowego, wyraziście określające się jako socjaldemokratyczne, czy w ogóle lewicowe (grupujące się wokół partii o analogicznej tożsamości - Unii Pracy i jej poprzedników, PPS), na wyróżnienie zasługują tu wystąpienia przede wszystkim aktywnych uczestników opozycji sprzed 1989 roku - prof. Tadeusza Kowalika, prof. Karola Modzelewskiego, a także aktywnych w latach 80-tych i 90-tych polityków Ryszarda Bugaja, Jana Józefa Lipskiego (zmarłego w 1991 roku) czy 
Piotra Ikonowicza. Drugą obok postsolidarnościowej lewicy grupę stanowiły środowiska SLD, które choć odgrywały nieporównywalnie większą rolę w polskiej polityce, to w dyskusjach ideowych i krytyce liberalizmu cechował je większy umiar i ostrożność, co wynikało ze specyficznych cech tej formacji politycznej ${ }^{1}$. Trzecią grupą były zaś osoby spoza świata polityki, ludzie nauki, w tym tak wybitni jej przedstawiciele, jak profesorowie Andrzej Walicki czy Leszek Nowak.

Antagoniści liberalizmu poddali w wątpliwość modernizacyjną rolę tej tradycji w polskich realiach, bądź to uznając jej całkowitą nieprzydatność i wręcz szkodliwość, bądź to konstatując jej niesamodzielność i konieczność syntezy liberalizmu z nieliberalnymi nurtami.

Na wstępie wyraźnie należy podkreślić, iż omawiane krytyki w nikłym stopniu odnosiły się do liberalizmu jako takiego. Wielu uczestników dyskusji zdecydowanie zastrzegało, że ich stanowisko dotyczy ściśle określonej mutacji tradycji liberalnej. Niejednokrotnie wskazywano na zbieżność aksjologiczną lewicowych z reguły antagonistów liberalizmu z tą tradycją. Płaszczyzna wspólnoty obejmowała ideał wolności jednostki. Tłem konstatacji bliskości była wspólna oświeceniowa genealogia ${ }^{2}$. Jednoznaczna akceptacja dotyczyła zatem w głównej mierze liberalizmu politycznego. Przyznawano, że stanowi on niezbędny komponent współczesnej demokracji (stanowiącej wszak dla socjaldemokracji - bo taka była orientacja większości dyskutantów - wartość autoteliczna). „W obronie demokratycznego państwa socjaldemokraci i liberałowie znajdują się po tej samej stronie, choć w kwestiach gospodarczych i społecznych bardzo wiele ich dzieli". Zdarzały się też głosy akcentujące okcydentalistyczny charakter różnych pooświeceniowych tradycji. Nie zaprzeczano zatem konieczności wytężonej modernizacji Polski, osiąnięcia standardów demokracji bliskich empirii większości państw świata zachodniego ${ }^{3}$. Można odnieść

1 Wyrastające z PZPR ugrupowania z obawą podchodziły do wszelkich tendencji ideologizacji. Zagrożenie zewnętrzne dla ich bytu politycznego ograniczało też możliwości wewnętrznych dyskusji, stąd dominował pragmatyzm - por. J. Wiatr, Socjaldemokracja wobec wyzwań XXI wieku, Warszawa 2000, s. 76, 83.

2 J. J. Lipski, Gtos w dyskusji, w: Liberalizm i socjaldemokracja wobec wschodnioeuropejskiego wyzwania, pod red. P. Marciniaka i A. Stadlera, Warszawa 1991, s. 191; T. Kowalik, Głos w dyskusji, w: ibidem, s. 151; P. Marciniak, Wobec prawicowego liberalizmu i chrześcijańskiego tradycjonalizmu. Trzeci nurt na polskiej scenie politycznej, „Przegląd Społeczny” nr 1, IV 1992, s. 4.

3 J. J. Wiatr, Socjaldemokracja wobec..., s. 115; M. Kowalska, Lewica wobec jednoczenia Europy. Refleksje na marginesie francuskiego referendum, „Przegląd 
do powyższych głosów stwierdzenie prof. J. Szackiego, iż pewne liberalne minimum stało się współcześnie powszechne, tak, że nie postrzega się go jako specyficznie liberalnego ${ }^{4}$.

\section{Krytyka ekonomizacji liberalizmu}

U źródeł negatywnych skojarzeń pojęcia liberalizm leżała teza o jego współczesnej asymetrii. Różnorodny, wielowątkowy dorobek idei liberalnych w praktyce politycznej został w mniemaniu jego adwersarzy zredukowany do liberalizmu ekonomicznego. Koncentracja zainteresowania środowisk liberalnych na gospodarce była silnie zakorzeniona w dziejach polskiego liberalizmu i nie stanowi ewenementu we współczesnym świecie $^{5}$.

Liberalizm w optyce jego pooświecniowych polemistów współcześnie przejawia się zatem przede wszystkim jako teoria ekonomiczna, dążąca do „gospodarki wolnego rynku o dominującej własności prywatnej”. Dostrzegano jednak głębsze założenia tkwiące u źródeł apoteozy wolnego rynku. Był to zresztą bodaj jedyny moment, w którym krytyka liberalizmu wkroczyła na grunt aksjologii. Oto bowiem odnaleziono wśród rudymentów liberalizmu radykalny indywidualizm i wizję homo oeconomicus. W efekcie współcześni liberałowie promują atomizm społeczny. Odrzucają jak to nazwał J. J. Lipski „wszelkie współdziałanie”. Pozostają nieufni wobec jakichkolwiek form asocjacjonistycznych. Absolutyzując jednostkową wolność kwestionują równość, stanowiącą warunek sine qua non realizacji oświeceniowego paradygmatu. Nie chcą uznać, że tylko równa wolność jest gwarancją wolności powszechnej. Paradoksalnie, promujący indywidualną zaradność apologeci liberalizmu są awangardą dekonstrukcji instytucji będących rezultatem spontanicznej aktywności. W praktyce polskiego liberalizmu po 1989 roku można wedle T. Kowalika odnaleźć

Społeczny" nr 6, X 1992, s. 29; R. Bugaj, Glos w dyskusji, w: Liberalizm i socjaldemokracja.., s. 150; P. Marciniak, Po neoliberalnym szoku, „Przegląd Społeczny” nr 9, I 1993, s. 23.

4 J. Szacki, Liberalizm po komunizmie, Kraków 1994, s. 15, 23-30.

5 N. Bobbio, Liberalizm i demokracja, Kraków 1998, s. 59; R. R. Ludwikowski, Gtówne nurty polskiej myśli politycznej 1815-1890, Warszawa 1982, s. 234; M. Śliwa, Polska myśl polityczna w I połowie XX wieku, Wrocław 1993, s. 134. 
„niszczenie instytucji samoobrony, niszczenie spółdzielczości [...], samorządu" .

Krytyka ekonomicznego leseferyzmu koncentrowała się na instytucji rynku. Liberalizm to bezrefleksyjna pochwała wolnego rynku, uznanie nieomylności i sprawiedliwości wszelkich jego rozstrzygnięć. Pojawiały się nawet motywy determinizmu i automatyzmu w działaniu rynku, jego omnipotencji, decydującym wpływie na różne dziedziny życia społecznego. Postępuje więc ekonomizacja życia społecznego, wszystko traktowane jest w kategoriach zysku. Naiwna wiara liberałów „w niewidzialną rękę rynku" może wręcz zagrozić podstawom cywilizacji. Rynek zatem stoi w sprzeczności z podstawowymi wartościami etycznymi, w rezultacie zagraża także prawom obywatelskim. Nie może być tak, „,by nieetyczne stosunki ekonomiczne traktowano jak prawa moralne, według których musi funkcjonować całe społeczeństwo" - przekonywał K. Modzelewski. Nie należy ulegać złudzie istnienia „naturalnych praw rynku”, niepodlegających weryfikacji ze strony człowieka. ,Zbyt łatwo ulegliśmy liberalnej tezie, że intensywny wzrost gospodarczy może odbywać się tylko kosztem takich wartości, jak równość [...]" - samokrytycznie przyznawano. Wielokrotnie wskazywano na dramatyczne skutki społeczne - pauperyzację, bezrobocie, drastyczne nierówności. Liberalizm promuje swoisty darwinizm społeczny - ,ideologowie czasu transformacji przekonują, że biedni są sami winni swojej biedy" - zarzucano rządzącym liberałom. Wolny rynek pozostaje redystrybutorem bardzo dalekim od doskonałości ${ }^{7}$. Stawiano mu nie tylko etyczne zarzuty. Twierdzono, iż jest nieskuteczny i nie potrafi zrealizować celów stawianych przez promotorów. Przede wszystkim ograniczone pozostają jego zdolności modernizacyjne.

${ }^{6}$ R. Gortat, Liberalizm jako konstruktywizm, „Przegląd Społeczny” nr 6, X 1992, s. 19; P. Marciniak, Po neoliberalnym szoku..., s. 19; W. Orliński, Dlaczego nie można być konserwatywno-liberalnym socjalista, „Lewą Nogą” 1993, nr 1, s. 36; T. Kowalik, Mój rok 1989, „Gazeta Wyborcza” 23-24 III 2002.

K. Modzelewski, Dokad od komunizmu, Warszawa 1993, s. 29, 116; R. Gortat, Liberalizm jako konstruktywizm..., s. 19-20; A. Łukaszewicz, O wartościach w programie lewicy, „Zeszyty Naukowe Instytutu Badań Społecznych i Międzynarodowych Fundacji im. Kazimierza Kelles-Krauza" 1998, nr 3, s. 40; J. Wawrzyniak, Kilka nieuporzqdkownych refleksji na temat lewicy w Polsce, ibidem, s. 61; Z. Sadowski, Zjawiska kryzysowe w gospodarce światowej $i$ ich wplyw na polska gospodarkę, „Myśl Socjaldemokratyczna" 1994, nr 2, s. 97; P. Ikonowicz, Pracy i chleba, Warszawa 2000, s. 25; tenże, Sprawiedliwe, stuszne i zbawienne, „Wiadomości Kulturalne”, 4 III 1995; M. F. Rakowski, w: O prawdziwych zadaniach polskiej lewicy, „Myśl Socjaldemokratyczna" 1999, nr 1, s. 10. 
„Z Trzeciego Świata do Europy żaden mechanizm rynkowy jeszcze nikogo nie doprowadził". Rynek cechuje się tendencją do monopolizacji, wyniszczającą konkurencją. Dążenie do jak najszybszego zysku często okazuje się być krótkowzrocznością ${ }^{8}$. Receptą jest zapobieżenie rynkowemu monizmowi. Musi być on uzupełniony, ograniczony instytucjami nie nastawionymi na działanie w kategoriach zysku. Wedle J. J. Lipskiego „decyzje ekonomiczne powinny uwzględniać także kryteria moralne i społeczne". Gospodarczą efektywność należy skojarzyć z zasadami sprawiedliwości społecznej. Rynek jest stopniowalny. Żaden kraj w praktyce nie zaakceptował pełnej omnipotencji wolnego rynku. Dlatego przeciwstawiano się liberalnym dążeniom do swego rodzaju „dymisji państwa” w gospodarce i polityce społecznej. Dominowały w omawianych środowiskach głosy broniące państwa opiekuńczego, jego redystrybucyjnych funkcji, choć dostrzegano z reguły konieczność jego modyfikacji, przede wszystkim zwiększenia roli czynnika społecznego, samorządowego. Nowoczesna gospodarka nie może sprowadzać się do spontanicznych zachowań rynkowych, niezbędny jest element planowości w imię racji społecznych. Tylko ograniczony, wpisany w szeroką sieć zależności, rynek ujawni swe zalety. Dowodzi tego doświadczenie państw zachodnich ${ }^{9}$. Trudno jednak byłoby skonstatować, iż owe krytyki rynku stawały się prostą jego antytezą. Zgodnie, niezależnie od partyjnych preferencji podkreślano, że rynek stanowi niezbędny komponent gospodarki i życia społecznego, zasługuje wręcz na instytucjonalną ochronę. Uwzględnienie racji społecznych nie może oznaczać totalnej eliminacji wolności gospodarczej. Istotą pozostaje walka ze skutkami społecznymi swobód ekonomicznych, a nie z ich istnieniem. Paradoksalnie zatem rynek musi być zarazem ograniczany, jak i ochraniany ${ }^{10}$. Niemal taki sam sposób my-

8 A. Celiński, Sens polityki. Sprawdzone wartości - nowe wyzwania, „Myśl Socjaldemokratyczna” 1999, nr 4, s. 8; P. Ikonowicz, Nowa Lewica, „Robotnik” nr 138, 15 XI 1988; tenże, w: Bład w rozumowaniu. Z P. Ikonowiczem rozmawia W. Orliński, „Robotnik” nr 8406, I 1993.

9 K. Modzelewski, Wobec historycznego wyzwania, „Przegląd Społeczny”, nr 1, IV 1992, s. 2; K. Wolicki, Czas konfliktów i sprzeczności, w: Polska przed nowymi problemami. Barometr społeczno-ekonomiczny 1999, Warszawa 2000, s. 132; P. Ikonowicz, Czy kapitalizm jest reformowalny, „Lewą Nogą” 1996, nr 1-2, s. 10-11.

10 A. Łukaszewicz, Państwo - gospodarka - społeczeństwo obywatelskie, „Myśl Socjaldemokratyczna" 1994, nr 2, s. 43; T. Kowalik, Szwedzkie doświadczenie w polskiej perspektywie, „Przegląd Społeczny” nr 3, VI-VII 1992, s. 46; K. Modzelewski, Głos $w$ dyskusji, w: Liberalizm i socjaldemokracja..., s. 31. 
ślenia towarzyszył krytykom kolejnego dogmatu liberalnej ekonomii jednoznacznej pochwale „świętej” własności prywatnej. Liberałowie przedkładają prawo do posiadania własności nad inne. Tu również, obok zahaczających o kwestie etyczne zagadnień nierówności, odkreślano problemy z efektywnością ekonomiczną gospodarek z dominacją sektora prywatnego. Wskazywano, iż zgodne z logiką nowoczesnej gospodarki są różne formy własności, także społecznej. T. Kowalik zarzucił rodzimym liberałom, iż automatycznie kopiują anglosaskie koncepcje redukujące prawo własności do wiązki praw właściciela. Jednocześnie nie zaprzeczano nieodzowności obecności sektora prywatnego ${ }^{11}$.

\section{Liberalizm jako rezultat ideowej zdrady}

Bardzo wiele miejsca poświęcano problemowi źródeł dominacji liberalizmu w polskim życiu politycznym i ekonomii po 1989 roku (szczególnie chętnie czynili to politycy i publicyści z kręgów postsolidarnościowej lewicy).

Genezy fenomenu liberalizmu poszukiwano w okresie PRL, przede wszystkim w specyfice sytuacji solidarnościowej opozycji po stanie wojennym. Wówczas to, ruchy wyrastające z opozycji, zepchnięte do konspiracji traciły tak charakterystyczną dla lat 1980-1981 więź z ruchem masowym, zdominowanym przez wielkoprzemysłową klasę robotniczą. Nie spodziewano się wówczas rychłego końca systemu. Zupełnej atrofii podległa też ideologia komunistyczna. „Rozkład komunizmu stworzył więc przestrzeń prowokującą wręcz pojawienie się nowego projektu ideologicznego, najlepiej importowanego, skoro wszystkie miejscowe tezy i antytezy legły w gruzach"12. O wyborze ideologii liberalnej przesądziły przede wszystkim dwa czynniki. Pierwszy związany był z tym, że ,przełom polityczny w Polsce następował w szczytowym momencie ofensywy neoliberalizmu na świecie". Miało to wielki wpływ m.in. na inteligencję

11 T. Kowalik, Głos w dyskusji..., s. 146; tenże, Prywatyzacja czy gospodarka mieszana, w: Losy idei socjalistycznych $i$ wyzwania współczesności, pod red. W. Wesołowskiego, Warszawa 1990, s. 57, 105; J. J. Wiatr, Co nam zostało z tych lat. Szkice i polemiki, Toruń 1996, s. 114; P. Bożyk, „Trzecia droga” Tony Blaira i Gerharda Schroedera a polska lewica, „Myśl Socjaldemokratyczna” 1999, nr 3, s. 39.

12 K. Modzelewski, Doką od komunizmu..., s. 29; P. Marciniak, Koniec epoki „,Solidarności”, „Przegląd Społeczny” nr 5, IX 1992, s. 2; R. Gortat, Liberalizm jako konstruktywizm..., s. 20. 
poszukującą zachodnich wzorców modernizacji dla zacofanego kraju. $\mathrm{Na}$ Zachodzie apogeum przeżywała moda na wolnorynkową ekonomię. $\mathrm{Na}$ polskich polityków najsilniej oddziaływały wzorce wykreowane przez R. Reagana i M. Thatcher ${ }^{13}$. Drugi czynnik wypływał z samego charakteru neoliberalnej oferty. Powstałą ideową próżnię najłatwiej było wypełnić „zapożyczoną, wyrazistą, zrozumiałą dla każdego polityka ideologią". Adaptacja liberalnych dogmatów dokonała się błyskawicznie, wszak ich standardy cechował symplicyzm. Skoro liberalizm wygrał w skali globalnej, to znaczy, że posiadł absolutną rację. Nowa ideologia nie miała na celu reformy starego systemu, ale jego całkowite odrzucenie. „Kolorowy świat liberalnej filozofii kontrastuje z szarą rzeczywistością PRL”. Neoliberalny monizm dawał jasne kryteria oceny rzeczywistości, ekonomizując wszystko pozwalał pominąć złożony charakter zaistniałej rzeczywistości, jej rozliczne konteksty. Podzielone politycznie elity dekomponującej się przecież w latach 80-tych opozycji spajał nowy, nieskomplikowany wzorzec. Jego schemat uczynił z ekonomii niemal jedyny punkt odniesienia. Nieprzypadkowo decyzje o kierunku reform zapadły faktycznie w wąskim gronie właśnie ekonomicznych ekspertów. Korelowała z tym trwająca do chwili obecnej ignorancja klasy politycznej w Polsce, jeśli chodzi o wiedzę ekonomiczną ${ }^{14}$.

Triumf liberalizmu możliwy był poprzez potrójną zdradę. Pierwszym zdrajcą okazały się być solidarnościowe elity. Ruch ten wyrastał z szeregów wielomilionowego związku zawodowego o wyraźnie propracowniczym, lewicowym programie. „Ten ruch w chwili narodzin przywiązany był do ideałów równości i sprawiedliwości społecznej rozumianych w sposób właściwy głównie robotnikom" - przypominał K. Modzelewski. Takie ideały dominowały zarówno w szerokiej bazie ruchu, jak wśród jego elit. Krytyka systemu komunistycznego związana była m.in. ze sprzeniewierzeniem się przez rządzących oficjalnie deklarowanym ideałom $^{15}$. Stan wojenny położył kres bezprecedensowemu demokratyzmowi

13 T. Kowalik, Wobec globalizacji nierówności, „Zeszyty Naukowe...” , s. 24; R. Gortat, Wolność bez demokracji (Studium przypadku: Polska 1989-1991), „Przegląd Społeczny" nr 2, V 1992, s. 16; K. Modzelewski, Doką od komunizmu..., s. 29.

14 P. Ikonowicz, Król jest nagi, „Lewą Nogą” 1993, nr 2, s. 24; tenże, Pracy i chleba.., s. 24; W. Orliński, Dwie wolności, dwa liberalizmy, „Lewą Nogą” 1995, nr 1, s. 7; R. Gortat, Liberalizm jako konstruktywizm..., s. 19.

15 K. Modzelewski, Dokąd od komunizmu..., s. 21, 82; Solidarność Pracy. Tezy programowe do dyskusji, „Po Prostu”, 6 IV 1991, s. I; PPS-RD wobec rzqdu T. Mazowieckiego, „Nasz Przegląd” nr 8, 25 IX 1989. 
„Solidarności”. Z ruchu masowego przetrwał mit i kadrowe organizacje naznaczone piętnem konspiracji. Oderwane od dawnego zaplecza elity stały się antykomunistyczną organizacją. Zaniknęła ich szczególna więź z uczestnikami ruchu. Kombatanctwo zastapiło wcześniejszą demokratyczną selekcję i rekrutację $\mathrm{kadr}^{16}$. Strajki 1988 roku organizowało młodsze pokolenie robotniczych działaczy. Rok 1989 nie dał takiego jak 9 lat wcześniej poczucia triumfu i w konsekwencji społecznego optymizmu. Elity bały się silnego związku zawodowego, który mógłby im zagrozić ${ }^{17}$. Kierownictwo zdradziło w tym momencie swe dawne zaplecze i ideały. „Znaczna część działaczy politycznych wywodzących się z »Solidarności« odwróciła się od [...] ideału sprawiedliwości społecznej” - oskarżał K. Modzelewski. Dokonano aksjologicznego zwrotu o 180 stopni. Symbol ruchu został instrumentalnie użyty dla obrony liberalnych reform. „Solidarność" z 1980 roku nie pozwoliłaby na plan Balcerowicza. Tak oto dokonał się przedziwny proces - ,z robotniczej rewolucji zrodził się dziki kapitalizm typu XIX-wiecznego" - zauważył T. Kowalik, tak jakby wśród 10 milionów członków pierwszej „Solidarności” „wszyscy [...] byli zwolennikami Miltona Friedmanna” - dodawał inny z dyskutantów ${ }^{18}$. Kontynuacją tej apostazji stały się rezultaty „okrąłłego stołu”. Negocjujących tam kwestie społeczno-gospodarcze inspirowały wzorce szwedzkie, m.in. filozofia społecznego dialogu. Tymczasem złamano przyjęte ustalenia, plan Balcerowicza nie uwzględniał dorobku negocjacji z pierwszej połowy 1989 roku. Zapewnienia premiera T. Mazowieckiego o „społecznej gospodarce rynkowej” T. Kowalik nazwał „mistyfikacją”. „Do niedawna powołująca się na wartości syndykalistyczno-socjaldemokratyczne, a później na wzory niemieckie, nowa elita polityczna prowadziła neoliberalną politykę skoku w rynek"19. Drugim aspektem zdrady wedle postsolidarnościowej lewicy stała się postawa środowiska utożsamianego z postaciami J. Kuronia czy A. Michnika. Prof. Leszek Nowak tak opisywał proces zarzucania lewicowych ideałów: „dominująca orientacja ideowa polskiej

16 K. Modzelewski, Dokad od komunizmu..., s. 26, 71.

17 S. Trzciński, 10 lat po Sierpniu, „Robotnik Mazowiecki” nr 5, IX 1990; K. Modzelewski, Dokad od komunizmu..., s. 71; tenże, Głos w dyskusji.., s. 33.

18 K. Modzelewski, Dokqd od komunizmu..., s. 82; tenże, Głos w dyskusji..., s. 34, 72; T. Kowalik, Nowy ład społeczny: ani konieczny, ani pożądany, w: Polska przed nowymi..., s. 36; W. Orliński, Obie kule u nóg, „Lewą Nogą” 1996, nr 1-2, s. 27.

19 T. Kowalik, Nowy ład społeczny..., s. 35; tenże, Ekonomiści polscy wobec nowego ładu ekonomicznego, w: Referaty na XIX Zjazd Oddziału Warszawskiego PTE, Warszawa 2001, s. 5. 
sceny politycznej w ostatnich dwóch dekadach przeszła zaskakującą ewolucję. Rozpoczęło się od anarchizmu KOR-u, którego patronem ideowym był Abramowski ze swą ideą budowy społeczeństwa poza państwem [...]. Stadium następnym był państwotwórczy socjaldemokratyzm tej orientacji w latach 1980-1981, [...] w każdym razie pozostała jednak [...] ta orientacja przez długie lata jeszcze w ramach myśli socjalistycznej. Ale jesienią 1989 roku przeszła na czysto liberalistyczny monetaryzm i zaakceptowała liberalną historiozofię [...]. Wszystko to skądinąd stało się bez jakichkolwiek publicznych dyskusji ujawniających racje tych zaskakujących zwrotów". Zerwanie miało zatem charakter gwałtowny, narodziła się charakterystyczna dla neofitów żarliwość ${ }^{20}$. Odstępstwo próbowano wyjaśniać różnymi argumentami. P. Ikonowicz wskazywał tu wydarzenia stanu wojennego, rozczarowanie tego środowiska klasą robotniczą, która uległa przemocy władz PRL. Odtąd ci opozycjoniści ,przestali wierzyć w ruch robotniczy", przyjęli neoliberalne tezy społeczno-ekonomiczne, skonstatowali bezsens podziałów na prawicę i lewicę. Po 1989 roku uznali robotników „za największego wroga reform”21. T. Kowalik tłumaczył tę nagłą woltę okcydentalistyczną orientacją środowiska post-KOR-owskiego, stawiającego sobie za cel integrację Polski z Europą i widzącego drogę do tego w modnym neoliberalizmie ${ }^{22}$. Dlatego prof. Z. Bauman dostrzegał, iż to ,z lewicy wywodzą się najzacieklejsi (jak na neofitów przystało) kapłani kultu Rynku Wszechwiedzącego [...]"23. Trzeci aspekt zdrady dotyczył całej polskiej inteligencji. Zwracał na to uwagę m.in. prof. Andrzej Walicki. Większość inteligencji bezrefleksyjnie zinternalizowała liberalny paradygamat, utożsamiając rynek z tym, co nowoczesne i postępowe. Zarzuciła ona swój tradycyjny etos służby ludowi, a także naturalny i pożądany dla ludzi wykształconych krytycyzm i sceptycyzm spojrzenia na rzeczywistość społeczną. „Szczególnie przykre wrażenie apostazji sprawili przedstawiciele nauk społecznych"24.

20 L. Nowak, O zagadnieniu tzw. transformacji ustrojowej, w: Społeczna transformacja w refleksji humanistycznej, red. K. Zamiara, Poznań 1994, s. 120; P. Marciniak, Po neoliberalnym szoku..., s. 22.

21 P. Ikonowicz, Nowa lewica...; tenże, Bład w rozumowaniu...

22 T. Kowalik, W stronę umowy społecznej, „Przegląd Społeczny” nr 1, IV 1992, s. 7.

23 Z. Baumann, O zadaniach lewicy, „Zeszyty Naukowe...”, s. 8.

24 A. Walicki, Czym nie powinna być inteligencja liberalna, „Przegląd”, 8 IV 1992; P. Kozłowski, Minęło 10 lat, w: Polska przed nowymi..., s. 126. 


\section{Liberalizm jako scjentystyczna i konstruktywistyczna ideologia}

Jeden z najpoważniejszych zarzutów wobec polskiego liberalizmu dotyczył utopijności. Oto bowiem omawiani antagoniści wolnego rynku uznali swojego ideowego oponenta za formę klasycznej niemal ideologii. „Zbiór jego dogmatów jest długi i stanowi oczywistą ideologię"25. Niejednokrotnie postponowano kruche legitymizacje liberalizmu. Popadł on w pułapkę scjentyzmu, gdy sam siebie odczytuje jako teorię naukową, wyrażającą obiektywne prawa, nie podlega więc osądowi laików, np. poprzez akt demokratycznych wyborów. Świat jawi się neofitom liberalizmu jako jeden wielki mechanizm, wolny rynek to miejsce ludzkiej samorealizacji. Esencją utopii pozostaje uznanie ekonomii za epicentrum całego życia społecznego ${ }^{26}$. Drugim filarem neoliberalizmu stała się historiozofia, w myśl której dzieje nieuchronnie i logicznie zmierzały do punktu finalnego w postaci kapitalizmu. Nauczycielem liberałów w tej materii miałby być Francis Fukuyama. „Dla zwolenników Fukuyamy i Wall Street uwieńczeniem historii nie jest komunizm, lecz wolnorynkowy kapitalizm globalny”. Następuje, jak to nazwał prof. L. Nowak, „kapitalistyczny koniec dziejów". Dlatego reprezentanci takich poglądów mają przeświadczenie, że reprezentują „dominujący nurt historii”. Daje im to „atrybut nieomylności”. Wszystko, co czynią jest z gruntu postępowe, gdyż stanowi pochodną wyroku historii. Jeden z polemistów w ferworze porównał powyższy scjentystyczny schemat do marksizmu-leninizmu ${ }^{27}$.

„Po 40 latach prób budowania komunistycznej utopii, klimat emocjonalny sprzyja budowaniu utopii liberalnej”. Specyfiką sytuacji był brak zaplecza społecznego w Polsce dla budowy kapitalizmu, którego historia wszak wiązała się z mieszczaństwem. W tym kraju nie istniała jednak „zorganizowana klasa właścicieli kapitału”. Brakuje znaczących sił społecznych zainteresowanych stworzeniem gospodarki rynkowej. „Idea mu-

25 K. Szumlewicz, Sąd nad lewica, „Myśl Socjaldemokratyczna” 2000, nr 1, s. 119 .

26 B. Stanosz, Przeciw fundamentalizmowi ekonomicznemu, „Myśl Socjaldemokratyczna" 2000, nr 2, s. 46; P. Ikonowicz, Pracy i chleba..., s. 30; W. Orliński, Dwie wolności..., s. 10, 12.

27 L. Nowak, Liberalizm i ,ukaszenie heglowskie”, „Lewą Nogą” 2000, nr 12, s. 342, 347; P. Ikonowicz, Czy nowy Marks znów ocali kapitalizm, ibidem, s. 8; tenże, Sprawiedliwe, stuszne... ; P. Kownacki, Rozwój społeczny a globalizacja gospodarki, „Lewą Nogą" 1999, nr 11, s. 87. 
siała więc zastąpić interes. W tej części Europy stosunki rynkowe nie rodziły się, lecz były tworzone wedle pewnego ideologicznego wzorca"28. Liberalizm popadał w bodaj największą wewnętrzną sprzeczność. Oto bowiem zarzucono mu tendencje konstruktywistyczne i etatystyczne. Cała polska transformacja ustrojowa została uznana za próbę wcielenia w życie utopii. To założenia ideologiczne wywierały decydujący wpływ „na kształt polityki państwowej i na kształt przyjmowanych rozwiązań gospodarczych”. Nastąpiła „ideologizacja procesu decyzyjnego i publicznego języka”. „Utopia liberalna w odniesieniu do gospodarki stała się obowiązującym stylem myślenia większości elit politycznych". Ustrój, który usiłowano zainstalować jego oponenci nazywali mianem kapitalizmu „XIX-wiecznego”, „latynoskiego”, „leseferystycznego”, „klasycznego"29. K. Modzelewski stwierdził, iż zastosowanie neoliberalnej historiozofii w Polsce oznacza dążenie do powrotu w punkt, z którego kapitalistyczna część świata rozpoczęła swój marsz ku rynkowi. Wedle tej deterministycznej wizji Polska musi przejść przez okres ,pierwotnej akumulacji kapitału, zbliżony do swego XIX-wiecznego pierwowzoru [...] z jego prywatną akumulacją, wyzyskiem i nierównościami”, niezbędna staje się zatem ,ekonomiczna i psychologiczna rewolucja liberalistyczna”. W sytuacji „bezwzględnej dominacji myślenia teleologicznego nad genetycznym, celu nad uwarunkowaniami", podstawowym pojęciem używanym przez liberalne elity staje się „budowa”. Rządzący w RP poczuli się do roli nośnika dziejowej prawdy, jedynego depozytariusza autentycznej wiedzy o istocie zmiany społecznej. Przemiany powinny radykalnie zerwać z przeszłością i dokonać się błyskawicznie. Wobec braku społecznych sił, których spontaniczny rozwój doprowadziłby do żywiołowej ekspansji rynku, liberałowie muszą odwołać się do jedynego istniejącego narzędzia zmiany społecznej - państwa. Odziedziczony po komunizmie scentralizowany sposób zarządzania państwem i gospodarką doprowadził w polskim liberalizmie do stanu współistnienia ,zasad wolnego rynku z koncepcją wszechwładnego państwa”. R. Gortat określiła to jako „etatystyczny konstruktywizm”. Na Zachodzie nikt ładu wolnorynkowego nie „budował”, w Polsce zaś usiłuje

28 R. Bugaj, Głos w dyskusji..., s. 161; R. Gortat, Liberalizm jako konstruktywizm..., s. 21; K. Modzelewski, Głos w dyskusji.., s. 31.

29 R. Bugaj, Głos w dyskusji, w: Liberalizm i socjaldemokracja..., s. 161; R. Gortat, Liberalizm jako konstruktywizm..., s. 21; J. J. Wiatr, Four Essays on East European Democratic Transformation, Warszawa 1992, s. 99. 
się go odgórnie stworzyć poprzez wzmożoną aktywność tak dezawuowanego przez leseferystów państwa ${ }^{30}$.

Naglony społeczną izolacją i neoficką wiarą w łatwość zmiany świata, konstruktywistyczny liberalizm obrał drogę ,skoku w rynek”. W swej naiwności J. Kuroń i inni wierzyli, iż będzie to operacja krótkotrwała, a nie skomplikowany proces społeczno-ekonomiczny. Dominowała perspektywa analizy rzeczywistości z punktu widzenia ,,prywatnego przedsiębiorcy". Abstrahowano od szerszego, nieekonomicznego kontekstu, co stanowiło efekt ekonomistycznej orientacji liberalizmu, w tym szczególnie oddziaływania chicagowskiej szkoły wierzącej w uniwersalność makroekonomicznych reguł. To wszystko nie korelowało raczej z gradualistycznym nastawieniem tej tradycji ideowej, w tym ostrzeżeniami samego F. Hayeka przed trudnościami zmiany całego systemu. Poza tym już w 1989 roku większość polskich ekonomistów przestrzegała przed skutkami „terapii szokowej”. Wedle T. Kowalika w efekcie „skoku” musiała narodzić się „chora, pełna patologii struktura społeczna ze zniszczonymi instytucjami społecznymi’’31. Konstruktywistyczny liberalizm uciekł się do inżynierii społecznej i dosłownej niemal klasowości. Liberałowie uznali się za reprezentanta interesów właścicieli kapitału czy w ogóle zamożniejszych warstw społeczeństwa - zwłaszcza mitycznej „klasy średniej”. T. Kowalik pisał o mieszczańskim charakterze polskiej rewolucji. K. Modzelewski oskarżał rządy prowieniencji liberalnej o to, że ich działania cechowała ,społeczna stronniczość [...] i klasowy charakter prowadzonej [...] polityki różnicowania dochodów". To właśnie stanowiło główny instrument realizacji ideologicznego celu. „Rewolucja w dochodach" w świadomy sposób kreować miała daleko idące nierówności. Ograniczenie redystrybucji, prywatyzacja to kolejne narzędzia liberalnej inżynierii $^{32}$. Była to prowadzona z premedytacją polityka maksymalnego

30 T. Kowalik, W stronę umowy..., s. 7; R. Gortat, Wolność bez demokracji..., s. 13, 16; tejże, Liberalizm jako konstruktywizm..., s. 21-23; C. Miżejewski, Bilans myśli, „Robotnik” nr 8405, 20 XI 1992; P. Ikonowicz, Czy biedni przegłosuja bogatych, „Lewą Nogą” 1998, nr 10, s. 9; W. Orliński, Dwie wolności..., s. 7.

31 T. Kowalik, Nowy ład społeczny..., s. 33; tenże, Mój rok 1989...; P. Ikonowicz, Pracy $i$ chleba..., s. 30, A. Siedlarek, Głosowanie nad dogmatem, „Unia Pracy Przegląd" nr 2, 21 XII 1992.

${ }^{32}$ T. Kowalik, Mit szkodliwości państwa opiekuńczego, „Myśl Socjaldemokratyczna" 2001, nr 3, s. 118; tenże, Ekonomiści polscy wobec..., s. 4; K. Modzelewski, Dokąd od komunizmu..., s. 21; P. Ikonowicz, Na lewo od rozumu, „Lewą Nogą” 1993, nr 1, s. 20. 
rozwarstwienia społecznego, bipolaryzacji, elitaryzacji dochodów. Doszło do dramatycznego paradoksu pierwotnej akumulacji kapitału, kiedy to biedni muszą płacić podatki po to, by wykreować grupę bogaczy. Ten mechanizm skutkować będzie dalszym pomnażaniem bogactw najzamożniejszych. R. Bugaj wskazywał, iż podstawą budżetu państwa są wpływy od biednych i średnio zarabiających. Im „,czystszy” będzie rynek i kapitalizm, tym bardziej dychotomia się pogłębi. Nierówności narosłe w Polsce są drastyczniejsze niż w innych państwach regionu ${ }^{33}$.

\section{Antydemokratyczny potencjał liberalizmu}

Najdalej idącym zarzutem wobec liberalizmu było wskazanie na jego antydemokratczny potencjał. Po pierwsze przypominano niedemokratyczną genezę kapitalizmu w Polsce. Plan Balcerowicza nie został poprzedzony społeczną dyskusją. Eksperymentalny nowy ład narzucono bez negocjacji z partnerami społecznymi i przy braku w pełni demokratycznych instytucji ${ }^{34}$. Wielokrotnie wskazywano na słabość społecznej legitymacji przemian. „Nowy ustrój społeczny nie znajduje akceptacji u większości społeczeństwa polskiego [...] jest traktowany jako narzucony [...] ”. „Konsekwentny liberalizm odrzucany jest więc przez niemal wszystkie grupy społeczne”. Wytworzyła się „niereprezentatywna struktura wpływu na rządzenie państwem". Pogłębia to delegitymację reformatorskich elit. Wyrażano obawy przed żywiołowym, gwałtownym społecznym wybuchem, który może nastąpić w przypadku kontynuowania neoliberalnej polityki $^{35}$. Kolejnym argumentem stało się przypomnienie ideologicznej rozbieżności liberalizmu z ideałem demokracji. Ta ostatnia dla liberała jest co najwyżej środkiem, a nie wartością samoistną. W. Orliński przypominał, iż współczesna demokracja, oparta na powszechnym i równym prawie wyborczym, narodziła się w walce $\mathrm{z}$ liberalizmem. R. Bugaj dostrzegał, iż ,są w Polsce siły polityczne [...], które skłonne są mówić, iż

33 R. Bugaj, w: Sprawozdanie Stenograficzne z 98 posiedzenia Sejmu $R P w d n$. 22 I 1997, s. 43; P. Ikonowicz, Pracy i chleba..., s. 27-36; J. Nowicki, Transformacja cywilizacyjna, „Myśl Socjaldemokratyczna” 1994, nr 2, s. 59.

34 T. Kowalik, Nowy tad..., s. 34; tenże, Mój rok 1989... .

35 T. Kowalik, Nowy ład..., s. 32, 33; tenże, Mit szkodliwości państwa..., s. 121; W. Orliński, Dwie wolności..., s. 7, 10; J. J. Wiatr, Dokad prowadzi ,trzecia droga” (Anthony'ego Giddensa poszukiwanie socjaldemokratycznej tożsamości), „Myśl Socjaldemokratyczna" 2000, nr 2, s. 45. 
demokracja nie jest celem samym w sobie, że są cele ważniejsze, względem których mechanizm demokratyczny musi być służebny”. Tym, co dla liberałów stanowi wartość nadrzędną pozostaje kapitalizm. Wskazywano też na destrukcyjny wpływ nierówności na demokrację. P. Ikonowicz dostrzegł, że współczesny kapitalizm w zglobalizowanej mutacji wyrwał się spod społecznej kontroli ${ }^{36}$.

Ze zdumieniem i oburzeniem wymieniano przykłady wypowiedzi liberalnych polityków i ekonomistów wychwalające Chile pod rządami Augusto Pinocheta $^{37}$. Wskazano także na wzajemną relewantność w polskich realiach liberalizmu i konserwatywnej prawicy, tradycyjnie sceptycznej wobec demokracji, epatującej hasłami wzmocnienia władzy wykonawczej, ograniczenia m.in. praw związków zawodowych. Obawiano się zatem, czy nie zostanie podjęta w praktyce próba jakiegoś autorytarnego wariantu w Polsce - pod hasłem priorytetu dla realizacji rynkowych reform gospodarczych, na czas których należałoby „zawiesić” funkcjonowanie demokracji wobec społecznego sprzeciwu dla nowego modelu społeczno-gospodarczego. W sytuacji braku przyzwolenia ze strony wyborców elity mogą dojść do wniosku, iż „mechanizmy demokracji są w gruncie rzeczy przeszkodą w naprawianiu gospodarki, ergo winny być ograniczone. Zbudowanie kapitalizmu staje się ważniejsze od demokracji”. P. Marciniak przedstawiał schemat tej antydemokratycznej tendencji następująco: „najpierw rynek bez demokracji, a więc rynek bez mechanizmu społecznego solidaryzmu i redystrybucji dochodów, rynek prowadzący do głębokiego zróżnicowania społecznego, a dopiero potem - gdy nagromadzenie narodowego bogactwa umożliwi załagodzenie konfliktów społecznych - stopniowe rozszerzanie demokratycznej regulacji”, ${ }^{38}$. Niebezpiecznym dla demokracji przejawem niedemokratycznych ciaggotek

36 W. Orliński, Dlaczego nie można być konserwatywno-liberalnym socjalista, „Lewą Nogą” 1993, nr 2, s. 32-33; P. Ikonowicz, Pracy i chleba..., s. 38; R. Bugaj, Póki nie jest za późno, „Polityka”, 27 VII 1992; tenże, Wystapienie na I Kongresie UP, „Przegląd Społeczny” nr 9, I 1993, s. 34.

37 P. Ikonowicz, Sprawiedliwe, stuszne i..., s. 7; S. Zgliczyński, Prawica a rasizm, „Lewą Nogą" 1007, nr 9, s. 10-11; W. Orliński, Dlaczego nie można..., ibidem, s. 33; tenże, Dwie wolności..., s. 11.

38 P. Marciniak, Demokracja: czas próby, w: Polska na rozdrożu, Warszawa 1993, s. 92; tenże, Po neoliberalnym szoku..., s. 23; T. Kowalik, Szwedzkie doświadczenie w..., s. 46; R. Gortat, Liberalizm jako konstruktywizm..., s. 21; A. Miłkowski, Głos w dyskusji, w: Liberalizm i socjaldemokracja.., s. 190; W. Orliński, 1989-przegrana rewolucja, „Lewą Noga” 1993, nr 2, s. 12; S. Zgliczyński, op. cit. 
liberałów było usilne wmawianie opinii publicznej tezy o bezalternatywności obranej przez Polskę drogi. Liberalni doktrynerzy postrzegają rzeczywistość w uproszczony, manichejski sposób. Skoro liberalizm zwyciężył w perspektywie historycznej, każdy jego oponent automatycznie staje się przeciwnikiem kapitalizmu, a więc w istocie zwolennikiem starego komunistycznego porządku ${ }^{39}$. Antydemokratyczne niebezpieczeństwo znajduje swój wyraz także we wszechogarniającej obecności tej ideologii i próbie zmonopolizowania przez nią wszelkich publicznych dyskusji. Na wszelkich sceptyków wywierana jest „,presja moralno-polityczna”. Liberałowie opanowawszy środki masowego przekazu nałożyli swoiste embargo na niewygodne dla nich tematy publicznej dyskusji. Bez ogródek T. Kowalik stwierdzał, że ,istnieje intelektualny i finansowy monopol powszechnie uznanych poglądów, który zastąpił formalną cenzurę". Poprzez monopol medialny liberałowie chcą zawładnąć społeczną świadomością ${ }^{40}$.

\section{Nieeuropejskość i prawicowość liberalizmu w Polsce}

Wielu oponentów liberalizmu twierdziło, iż mamy do czynienia z jego spektakularnym upadkiem, a casus Polski jest jednym z licznych tego dowodów. Będącą ofiarą ideologicznego eksperymentu Rzeczpospolitą cechuje największe w tym regionie Europy bezrobocie i nierówności, klientelistyczna prywatyzacja przecząca liberalnym obietnicom, przywraca się XIX-wieczne stosunki pracy. „W rezultacie spotkania się spontanicznych reakcji społeczeństwa z konstruktywistycznym działaniem władzy rodzi się twór swoisty, oparty na klientelizmie, korupcji, odrębności norm oficjalnych od stosowanych na co dzień przez ludzi”. Wedle T. Kowalika w Polsce stworzono jeden $\mathrm{z}$,najbardziej niesprawiedliwych ustrojów społecznych, jakie znała historia tego kontynentu drugiej połowy ubiegłego stulecia”. „Niewidzialna ręka rynku” okazuje się z reguły niewi-

39 J. J. Wiatr, Strategiczny wybór dla Polski, „Zeszyty Naukowe...”, s. 64; tenże, Strategia socjaldemokratyczna $w$ warunkach transformacji ustrojowej, „Myśl Socjaldemokratyczna" 1994, nr 4, s. 14; P. Marciniak, Demokracja: czas..., s. 91; R. Gortat, Liberalizm jako konstruktywizm..., s. 21.

40 P. Kozłowski, Minęło 10 lat..., s. 127; T. Kowalik, Ekonomiści polscy..., s. 9; tenże, Upór i bezinteresowność, „Myśl Socjaldemokratyczna” 2000, nr 4, s. 45; P. Ikonowicz, Pracy $i$ chleba..., s. 27. 
domą. Dzisiejszy kapitalizm pod wieloma względami jest dużo bardziej zdegenerowany niż ten funkcjonujący w bipolarnie podzielonym świecie. Problemy większości kapitalistycznego świata pogłębiają się. Ustrój montowany w Polsce przeżywa właśnie strukturalny kryzys o globalnym zasięgu $^{41}$.

Liberalizm jawił się jego antagonistom jako po prostu archaiczny, niezdolny do wypełniania misji modernizacyjnej. „Coraz mniej można dowiedzieć się o współczesnym świecie z czytanek von Hayeka czy Smitha”. Inny polemista zauważał, że „dla objaśnienia liberalnej doktryny nie potrzebne jest żadne słowo pochodzące spoza wieku XVIII”. W konsekwencji ,program realizowany w Polsce jest [...] archaiczny i doktrynerski - to symplicystyczna wersja liberalizmu" ${ }^{\prime 2}$. T. Kowalik i inni zwracali uwage na paraliż intelektualny liberalizmu w Polsce, który fetując triumf nad komunizmem popadł w marazm i powiela wciąż kilka swych nieskomplikowanych dogmatów. Polskie elity są głuche na trendy z Zachodu, gdzie toczą się dyskusje, w których podważa się neoliberalne aksjomaty. Swoista moda na antyegalitaryzm w rozwiniętych krajach przeminęła. „Tocząca się obecnie na świecie dyskusja, głównie w USA, na temat mankamentów liberalizmu friedmannowskiego nie jest odnotowywana w Polsce" - zauważał prof. Paweł Bożyk ${ }^{43}$. Bardzo ciekawym argumentem, w zastanawiający sposób nieobecnym w debacie europejskiej w Polsce, stał się zarzut nieuropejskości leseferystycznego liberalizmu. Europa i jej modele socjalne w optyce krytyków liberalizmu pozostają w niezgodzie z liberalnymi dogmatami. Polska transformacja w wielu aspektach idzie wbrew XX-wiecznej ewolucji kapitalizmu. Wskazywano, że wiele państw zachodniej części kontynentu przewyższa pod licznymi względami gloryfikowany przez liberałów model amerykański. T. Kowalik szczególnie chętnie odwoływał się do przypadku Szwecji, wskazując na fiasko liberal-

41 T. Kowalik, Nowy ład..., s. 28; tenże, Mój rok 1989...; P. Kozłowski, Minęło 10 lat..., s. 127; W. Warzywoda-Kruszyńska, Bieda i polityka, „Myśl Socjaldemokratyczna" 2000, nr 3, s. 43; J. Oleksy, w: K. Skarżyńska, Partia władzy czy partia ludu, ibidem 1999, nr 4, s. 106; P. Ikonowicz, Czy kapitalizm jest reformowalny, „Lewa Noga”" 1996, nr 1-2, s. 9; W. Orliński, 1989 - przegrana..., s. 5-8.

${ }_{22}$ P. Ikonowicz, Czy kapitalizm jest..., s. 9; W. Orliński, Dlaczego nie..., s. 31;

P. Kozłowski, Minęło 10 lat..., s. 129.

${ }^{43}$ T. Kowalik, Wobec globalizacji..., s. 20; tenże, Państwo opiekuńcze obroniło..., s. 138; B. Stanosz, Przeciw fundamentalizmowi..., s. 146; P. Bożyk, Problemy „trzeciej drogi": wokót Manifestu Socjaldemokratycznego Tony Blaira i Gerharda Schroedera, „Myśl Socjaldemokratyczna” 2000, nr 2, s. 26. 
nych prognoz jej bankructwa. Jeden z późniejszych premierów RP przestrzegał w 2000 roku, iż „Polska nie może być liberalno-prawicowym dziwolagiem na scenie europejskiej" 44 . Rodzimym liberałom zarzucano bezrefleksyjną fascynację Stanami Zjednoczonymi. Twierdzono, iż polska transformacja zinternalizowała ideologię amerykańskiego konserwatyzmu i generalnie hołduje wzorcom anglosaskim. Cały konstrukt i jego ideologiczna legitymizacja odległa jest od doświadczenia europejskiego. P. Kownacki zwracał przy tym uwagę, iż także sam model amerykański w swej praktyce, nawet za prezydentury R. Reagana daleki był w gospodarce od leseferyzmu ${ }^{45}$.

Wielu antagonistów liberalnych elit stwierdzało niereprezentatywność rodzimej mutacji liberalizmu dla całości tej tradycji ideowej. Szczególnie chętnie czynił to prof. A. Walicki, stwierdzający m.in., że „nasilenie ofensywy ideologicznej ekonomicznego liberalizmu, czyli po prostu nowej prawicy, oceniam jako zerwanie z głównym nurtem myśli liberalnej [...]. Jest to powrót do przeszłości, spencerowskiej apologetyki, wedle której bogactwo społeczne wytwarzają tylko prywatni przedsiębiorcy". Autor ten wskazywał, że wbrew stereotypom państwo opiekuńcze zrodziło się na gruncie „tradycji liberalnej, która już w XIX wieku porzuciła redukowanie wolności do wolnego rynku”. To „wolnorynkowi radykałowie” zawłaszczają ideę liberalizmu, sprowadzając ją do absolutyzacji rynku, tymczasem ideał wolności jednostki powinien zawierać imperatyw obrony przed każdą wszechwładzą, także przed hegemonią rynku. Adherenci Miltona Friedmanna powinni być określani jako „,nowa prawica”, „skrajna prawica", czy jak zauważali wybitni liberałowie Isaiah Berlin czy John Rawls - jako „libertarianie”. Dla prof. Sylwestra Zawadzkiego to „skrajnie konserwatywne skrzydło liberalizmu"46. Nowoczesny liberalizm zachodni przeszedł pozytywną ewolucję, w wielu aspektach zbliżając się do socjaldemokracji (i vice versa), czego dowodem jest kariera, jaką zrobiło

44 A. Walicki, Polska transformacja w perspektywie wartościujacej, w: Polska przed nowymi..., s. 130; T. Kowalik, Mit szkodliwości..., s. 119-120; tenże, Mogło być inaczej, „Gazeta Wyborcza”, 2 VIII 2000; L. Miller, w: Deficyt społecznej wrażliwości. Z L. Millerem rozmawia R. Łuczyńska, „Dziś” 2000, nr 2, s. 16.

45 R. Bugaj, Nowe wyzwania przed Polska, w: Polska przed nowymi..., s. 10; T. Kowalik, Ekonomiści polscy wobec..., s. 5-6, 12; P. Kownacki, Rozwój społeczny a globalizacja gospodarki, „Lewą Nogą” 1999, nr 11, s. 95.

A. Walicki, Polska transformacja w..., s. 130; tenże, Czym nie powinna..., s. 47-48, 50; S. Zawadzki, Wobec spornych problemów nowej konstytucji RP, „Myśl Socjaldemokratyczna" 1991, nr 1, s. 60. 
pojęcie „socjalliberalizmu”. Pojawiły się w jego obrębie różne koncepcje asocjacjonistyczne. Zrozumiał znaczenie kontekstu społecznego, psychologicznego, potrzebę jakiejś dozy bezpieczeństwa socjalnego ${ }^{47}$. Natomiast atrybutem jego polskiego wariantu jest, jak niejednokrotnie stwierdzano, „dogmatyzm”, „ortodoksyjność ”48. Warto dostrzec, iż to właśnie środowiska krytykujące z opisywanych pozycji liberalizm jako jedne z pierwszych w Polsce zaczęły posługiwać się pojęciem globalizacji i argumentacją charakterystyczną dla rodzących się na przełomie stuleci ruchów antyglobalistycznych $^{49}$.

Fragmentem polemiki z liberalnym establishmenetem stało się też zanegowanie lansowanych w Polsce głównie przez post-KOR-owską elitę tez o końcu „wieku ideologii” i bezsensie podziałów na prawicę i lewicę. Uznano, że to raczej próba zamazania własnego lewicowego rodowodu przez takie postacie, jak J. Kuroń czy A. Michnik. Ich świat pojęć jest „odrealniony". Po 1989 roku w demokratyzujących się państwach, w różnorodnych formach powstawały, bądź odradzały się ideologie. Zatem także diada lewica-prawica pozostaje ważną, mimo przeżywanego kryzysu ${ }^{50}$. Za główny spór współczesności, charakterystyczny dla dziejów kultury politycznej Zachodu uznano konflikt wokół zagadnień społeczno-ekonomicznych $^{51}$. Na tym tle konstatowano absurdy polskiej sytuacji, jej nie-

47 J. J. Wiatr, Socjaldemokracja wobec..., s. 97-98; T. Kowalik, Państwo opiekuńcze obroniło się..., s. 138; Z. Bujak, Między socjaldemokracja a liberalizmem, „Życie Gospodarcze”, 28 VII 1991; M. Kowalska, Szanse nowej lewicy, „Przegląd Społeczny" nr 3, VI-VII 1992, s. 26.

${ }^{48}$ R. Bugaj, Nowe wyzwania przed..., s. 10; P. Ikonowicz, w: Spr. Sten. z 98 pos. Sеjmu RP w dn. 22 I 1997, s. 54.

49 T. Kowalik, Wobec globalizacji..., s. 25; Z. Machelski, Polityczne problemy globalizacji, „Myśl Socjaldemokratyczna” 2001, nr 3, s. 54-56; P. Bożyk, Problemy „trzeciej drogi”..., s. 24; P. Kownacki, Rozwój gospodarczy a.., s. 100; P. Ikonowicz, Dlaczego trzeba protestować przeciw polityce MFW i Banku Światowego, „Robotnik Śląski” nr 8, VIII-IX 2000; tenże, Dlaczego PPS, „Robotnik” nr 10521, II-III 2000.

50 R. Bugaj, Porzadkowanie sceny politycznej, „Przegląd Społeczny” nr 4, VIII 1992, s. 37-38; tenże, w: Te niemodne wartości. Rozmowa z R. Bugajem, „Życie Warszawy", 10 I 1991; P. Marciniak, Wobec prawicowego liberalizmu..., s. 29-31; Rozmowa z J. J. Lipskim, „41 - pismo studentów UW” nr 3, I 1990; W. Giełżyński, Ani Wschód, ani Zachód, Warszawa 1989, s. 121.

51 J. J. Wiatr, Socjaldemokracja wobec wyzwań..., s. 97; I. Różewicz, Kilka uwag o projekcie programu PPS, „Robotnik” nr 11, 2 II 1989; O. Marciniak, Wobec prawicowego liberalizmu..., s. 29; P. Ikonowicz, Pracy i chleba ..., s. 9; J. J. Lipski, w: „41 pismo..." 
adekwatność do realiów społecznych oraz niekoherentność z podziałami socjopolitycznymi demokratycznych państw Zachodu, np. prof. Baumann zauważył, że skrajnie prawicowe „ruchy antywolnościowe” głoszą „,hasła równościowe”. Inni dyskutanci wskazywali na swoiste „,prawicowe skupienie" sceny politycznej w Polsce, gdzie brakuje ściślejszej korelacji interesów wielkich grup społecznych z partiami i w rezultacie niereprezentowane pozostają słabsze społecznie grupy ${ }^{52}$. Z dystansem podchodzono do konfliktów o charakterze kulturowym, skupionych wokół takich wartości jak tolerancja, w praktyce zaś ogniskujących społeczne emocje choćby na kwestiach relacji państwo-kościół czy aborcji. To kwestie społeczno-ekonomiczne winny być w centrum uwagi. Nieprzypadkowo lewicowe formacje we współczesnej Polsce nie godziły się na kreślenie osi podziałów socjopolitycznych wedle kwestii kulturowych ${ }^{53}$.

\section{Podsumowanie}

Rekapitulując podkreślić należy wielowątkowość dyskusji o liberalizmie we współczesnej Polsce, choć jednocześnie jego niekonserwatywne krytyki dotyczyły niemal wyłącznie zjawiska liberalizmu ekonomicznego. Zauważyć też można nikłą obecność rzeczonych krytyk w środkach masowego przekazu, pomimo tego, że ich autorami w wielu przypadkach byli znani przedstawiciele nauki i czynni politycy. Większość cytowanych tekstów pochodzi z raczej niszowych wydawnictw. Trudno również byłoby znaleźć ślady bezpośredniego wpływu omawianego nurtu na prowadzoną przez kolejne rządy RP politykę. Jest to o tyle ciekawym zjawiskiem, iż znaczna część prognoz wysuwanych przez promodernizacyjnych oponentów liberalizmu sprawdziła się, choćby odnośnie wzrostu rozwarstwienia majątkowego w społeczeństwie czy niekoherentności liberalnych programów z doświadczeniem zachodnioeuropejskim (vide kwestia podatku liniowego nieobecnego w zachodniej części kontynentu). Można też uznać, iż takie krytyki liberalizmu same w sobie stanowiły próbę okcydentaliza-

52 Z. Baumann, op. cit., s. 8; R. Bugaj, Porzadkowanie sceny politycznej..., s. 37-38; P. Ikonowicz, XXV Kongres PPS. Referat polityczny, Warszawa 1990, s. 3.

53 T. Kowalik, Mogło być inaczej...; czyt. szerzej, R. Chwedoruk, Między ewangeliq a antyklerykalizmem. Socjaliści i socjaldemokraci wobec religii i kościoła $w$ Polsce, w: Polska na nowej drodze. Tradycja i współczesność, pod red. A. Magierskiej, „Studia Politologiczne” 1997, nr 2, s. 67-84. 
cji dyskursu politycznego w Polsce, nawiązując do narastającego na Zachodzie krytycyzmu wobec „konserwatywnej rewolucji”. Paradoksem zaś była swoista liberalna krytyka liberalizmu, stawianie rodzimym admiratorom leseferyzmu zarzutów tradycyjnie wysuwanych uprzednio przez liberałów wobec ich adwersarzy, np. jeśli chodzi o kwestie konstruktywizmu. Jednym z istotniejszych i inspirującym do dalszych analiz powinno być pytanie czy wszystko to w większym stanowiło próbę ataku przeciwko tradycji liberalnej w ogóle, czy też było fragmentem sporu o interpretację tradycji liberalnej?

\section{Summary}

The great political transformations in Poland after 1989 have made the notion of broadly understood liberalism the core of political discourse. There have emerged frequent claims of significant or even critical influence of this idea on the model of social, economic and political reforms. At the same time, an increasing discrediting trend of varied origins has emerged. The purpose of this paper is to present the key themes of critics of liberalism speaking from a pro-modernization point of view, i.e. those who accept the broadly understood Enlightenment paradigm and approve the imperative civilization modernization of Poland by means of its occidentalization. The discourse of liberal reformers with their opponents to a certain degree reflects the mythological dichotomy of the left and the right, although not many participants in the dispute have necessarily had to identify themselves in this respect. 